\title{
The Quality of Teachers in Digital Era
}

\author{
Robie Fanreza \\ University of Muhammadiyah Sumatera Utara \\ robiefanreza@umsu.ac.id
}

\begin{abstract}
In digital era, Education has become new challenge for Teachers that need to pay attention for. If the learning system still applies a conventional system, it may be behind the modern education system. In digital era, the process of learning and teaching is not only focused in the classroom, but also by using digital media, online and teleconference. However, the students must be controlled by the teachers, so they can choose positive aspects of technological advance. And the teachers as the main role should keep on watch and have to smarter than the students in technological issues.
\end{abstract}

Keywords: Quality, Teacher, Digital Age

\section{INTRODUCTION}

The existence of teachers among students becomes important, because the teacher is the main learning resource for the students. As a source of learning, teachers must prepare themselves with all required skills to transfer knowledge to students. Of course with the ability of a teacher will make the students with very easy to accept knowledge. Thus a female teacher in the teaching and learning process has many functions, as teachers and educators. Therefore a teacher should be has a huge responsibility to achieve the progress of education. Because so much the task of a teacher in teaching the progress of education can be said lies on a teacher.

Indonesian education will be brilliant if a teacher as a centralized ability in the education stem has a good quality. And quality education processes, involving various inputs, such as teaching materials (cognitive, affective and psychomotor), methodology (varies according to teacher's ability), school facilities, administrative support and other infrastructure and resources and create a conducive atmosphere. School management, class support serves to synchronize the various inputs. Among others, synergize all components in the interaction (process) of teaching and learning, both between teachers, students and support facilities in the classroom or outside the classroom, both curricular and extra-curricular contexts, both within academic and non academic sub-areas in an atmosphere that supports the process learning.

Child and Adolescent Psychologist University of Indonesia (UI) Vera Itabiliana Hadiwidjojo assess, currently education in the country is still in the process of shapping a better mental quality, both from teachers and students. This digital era and social media, according to Vera, provides a greater challenge for teachers. "How to maintain the mental quality in which various information can enter quickly," he said to JavaPos.com, Tuesday $(2 / 5)$.

Vera added that it requires a strong filter from teachers to sort out what's right or wrong, which can unknowingly affect mental quality. For example, he said, the value of promiscuity among teenagers or students. "What is taught in schools should have a clear applicative impact in real life," he explained. Vera added that students need to be invited to see the benefits of what is learned in school. Teachers also need to be creative and able to approach a fitting with the age of students. "So students can continue to be enthusiastic about what they are taught, and teachers should be more creative," he said.

Why the quality of teachers at this time can be said to decline. There are few teachers who have to earn a living or money other than he gets from his duty in teaching. There is even a teacher who has become a scavenger, motorcycle taxi on-line or other work other than teachers. This will reduce the education quality in Indonesia. Teachers also determine the success of learners, especially in relation to teaching and learning in the classroom. Teachers become creators and determinants in the effort of creating quality process and learning outcomes. Teachers also serve as a model for learners. So in this case the teacher should always improve the quality in teaching and educating students.

\section{Understanding Qualified Teachers}

What is a qualified teacher, according to a qualified teacher's law. Teachers or educators in Article 1 Paragraph 6 of Law no. 20 of 2003 on National Education System stated that "Educators are qualified personnel as teachers, lecturers, counselors, guardians, widyaiswara, tutors, instructors, facilitators, and other designations in accordance with the specificity, and participate in the provision of education. Furthermore, Article 39, paragraph 2, stated that: "Educators are professionals in charge of planning and implementing learning, assessing learning outcomes, conducting guidance and training, and conducting research and community service, especially for educators at universities".

In the Indonesian dictionary mentioned quality (in English quality) has a good sense of the level of certain thing, the degree, or the quality of something [1] . Hence, quality is the level or good of bad things either in the form of objects or humans. While the understanding of teachers in Indonesian dictionary interpreted as a person whose job (livelihood a ) is teaching. In the English dictionary found a teacher who means teacher [2]. In addition, there is a word tutor which means a private 
teacher who teach at home, teaching extra, giving additional lessons.

And in Arabic terms many words refer to the understanding of the teacher and are very diverse ranging from the word mu'allim (al-a lim is the plural form of ulama) which means people who know and widely used by scholars / educational experts to point to the heart of the teacher other than that others use the term al-mudarris for the meaning of the person teaching or the person giving the lesson, and some are using the term almuaddib which refers to the teacher who specifically taught in the court [3].

According Nurul Yaqin, a teacher of Junior High School of Islamic Integrated (SMPIT) Annur, East Cikarang, Bekasi. Millenial student What is the collective problem of our education world today is the teacher of the twentieth century (who was born before the year 2000) still stuttering the technology. While the students faced is a man of the XXI century is certainly different in the nutritional intake of scientific technology. Simply put, many of our students today are smarter in term of technology than their teachers. Such a gap cannot be left alone so as not to cause any fatal incident in the education process.

Since the New Order era teachers are no longer resemble the description by Earl V Pullias and James D Young in their book A Teacher is Many Things who refer teacher as a figure of all-round creatures and have high authority in the presence of his students or society. But, the current teacher figure is more appropriate as a mimicry figure, who must be clever to adapt in accordance to time and situation. It is as a result of the existing ideological, political, economic, social and cultural situation is very dominant.

The emergence of communication media that is not only based on the message (audio) has cause a new addiction among our young generation. Especially communication application that comes with audio visual media. Many students watch negative images which they think is something trendy. Ironically, teachers do not know what their students are doing because they do not have similar applications. This is a problem that cannot be underestimated. Through one of the most beloved apps, today's teenagers are competing to upload their most prestigious photographs.

An unlimited application of communication will bring children to a more free and wild world. They get in touch and interact with the idol figures such as Korean artists, Hollywood artists, and others. In fact, they make it as a mecca in its acts.

This will be the biggest challenge for teachers. Sophisticated technology will cause communication among students can be intertwined with a secret. When cyberspace chatting between students without parents and teachers, it is very risky they will act in accordance with the lust of young soul. The lust of a young soul tends to be without any consideration of reason which can of course have a negative impact on them [4] said, "Technological advances have the potential to make children satisfied with the knowledge they gain, thus they assume what is obtained from the internet or other technology is the most complete and final knowledge".

\section{Technology Literate}

The technological quality of teachers who are empty of technology will not be able to instill "critical power" to the students to become revolutionary human beings. So they are hampered to explore his potential. Teachers who do not keep an update with current technology (technological stutterers) will lower their credibility in front of their students so that students tend to be underestimated, as if the teacher is a fool in the middle of the metropolitan world.

This is a phenomenon that often exists and occurs around us. Some teachers so-called belong to the generation of the 90s, but they should keep up and improve their knowledge in accordance to the current technology.

A teacher must be better in skill and ability than his/her students, not only in the pedagogical context but also must be updated in all areas. Teachers where students stand, if the teacher is not there spirit to increase his potential, it is certain the teacher will lose from the level of scholarship of his students, given the source of learning is now landing in cyberspace every second. In response, teachers should not stutter technology and should always try to motivate themselves in the world of technology. Teachers should not be lazy to access information and technology if they do not want to be left behind.

They need to learn seriously to be able to operate the information technology tool in front of the students. Professional teachers will more easily understand the needs of students in the middle of the full availability of facilities and infrastructure. When students have accounts in social media, there is no harm if teachers also have it, even they are suggested to be friends. In addition to being a forum for learning, communication media, and information dissemination, the presence of teachers as well as supervisors of student activities when surfing in cyberspace. Student communication today tends to be acting too much and in the form of symbols that are difficult to reach by adults. In this case, teachers need to know the language that they often use. Sometimes in the language they use the elements that plunge into uncivilized actions.

\section{Qualified Teacher Features}

How to qualify teachers professionally in the age of the digital age. In the Educational Leadership [5] writes that to be a professional, a teacher is required to have five things:

1. The teacher is committed to the students and the learning process. This means that the teacher's highest commitment is to interests of the students.

2. Master and utilize classical and modern learning media [6]-[7] 
3. Teachers deeply master the material / subjects taught and teach it to students. For teachers, these are two things that cannot be separated.

4. Teachers are responsible for monitoring student learning outcomes through various evaluation techniques, ranging from observations in student behavior to learning outcomes.

5. The teacher is able to think systematically about what he does, and learn from his experience. That is, there should always be time for teachers to make reflections and corrections to what is has done. To be able to learn from experience, he must know what is right and wrong, and good and bad impact on student learning process.

\section{CONCLUSION}

A teacher that is considered as a professional in the digital era is not only having the ability in education and mastering educational technology, but also ability or have intrapersonal, intellectual, emotional and spiritual intelligence. Therefore, the reward given to the teacher will be enough, and no more teachers have to have double job or wrestle other jobs. Of course with the quality of a good teacher in the digital age will make it easier for students to do the learning process.

\section{REFERENCES}

[1] Abudinata. Islamic Perspective On The Pattern Of Master-Discipleship Relations, Studies Of Thought Of Mysticism Imam Al-Ghazali. Jakarta: Raja Grafindopersada. 2001.

[2] Gultom, Jj. Media Utilization in Teaching Learning Process. Journal of Education . 2012.

[3] Pratomo, A. Designing Interactive Web Based Media Using The Promethee Method. Journal of Information Technology of Asia . 2013.

[4] Shadily, (John M. Echols And Hasan. English Dictionary Indonesia (Cet.XXIII) Jakarta: Gramedia Pustakautama. 1996.

[5] Subqi, I. Importance Of Intrapersonal Intelligence In Learning Of Islamic Religious Education. At-Tajdid: Journal of Tarbiyah sciences . 2013.

[6] The Compilation Team of P3b Dictionary. Big Indonesian Dictionary (Edition D). Jakarta: Balaipustaka. 1996.

[7] Zamroni, A. Improvement Esq (Emotional Spiritual Quotient) Students SMAN 1 Pacitan Through Learning Religious Education Islam. At-Tajdid: Journal Of Tarbiyahsciences. 2014. 